\title{
Estimation methodology and the significance of the atmospheric water exchange flux in the river-lake systems of selected lobelia lakes in the vicinity of the Tri-City in Poland
}

\author{
Maciej Markowski ${ }^{*}$, Włodzimierz Golus \\ Department of Limnology, University of Gdańsk, Bażyńskiego 4, 80-309 Gdańsk, Poland e-mail: maciej.markowski@ug.edu.pl \\ (M.M.; *corresponding author), wlodzimierz.golus@ug.edu.pl (W.G.)
}

\begin{abstract}
The article aims to present the methodology of estimating the atmospheric water exchange components in the lake. In the absence of direct precipitation and evaporation measurements, these water balance elements need to be estimated. However, the inadequate selection of precipitation and evaporation estimation methods causes the incorrect determination of the hydrological function of the lake and the effect it has on the formation of river drainage. Determination of the evaporation from the lake's surface was based on the Davidov formula, which considered the monthly average surface temperature of a given lake. The saturated water vapour pressure under the lake's monthly mean surface water temperature (TWP) was calculated according to ISO 13788 standard. The interpolation method, which is the inverse-distance deterministic method (IDW), was used to calculate precipitation reaching the lake surface. The calculations were made for three hydrological years diverse in terms of humidity and thermal conditions. The methodology for estimating the components of atmospheric water exchange was presented on a small river-lake system of the upper Gościcina River catchment, an example of a postglacial lake district area. The lake elements of this system are lobelia lakes, poorly known in terms of water circulation. At the beginning of the twenty-first century, unjustified activities regarding assessing the water circulation conditions in this river-lake system led to changes in water relations, causing environmental, financial and social losses.
\end{abstract}

Key words: lobelia lakes, water balance, evaporation, precipitation, river-lake systems

\section{Introduction}

To characterise the area of Northern Poland, one should recall the common notion that it was shaped due to the ice sheet activity. This, together with the activity of meltwaters and subsequent morphogenetic processes, turned Northern Poland into a typical lake district. The spatial diversity of the young glacial landscape results not only from the relief and geological structure but is also conditioned by numerous hydrographic objects (Bajkiewicz-Grabowska et al. 2020a). At the same time, the poor organisation of the surface drainage network means postglacial areas show initial development of their hydrographic networks. In addition to various types of watercourses (permanent, periodic, episodic), springs, seepages, and swamps are crucial elements. An important link connecting the objects mentioned above and influencing the formation of the river outflow is the morphometrically diverse lakes (BajkiewiczGrabowska 2007; Drwal 1982). The morphological and hydrological interrelationship of lakes and watercourses in shaping the river outflow and their arrangement in the water network structure leads to using the term river-lake network. Bajkiewicz-Grabowska (2002) indicates that these are the lake sections, and not the river stretches, that determine the size of the river runoff in such a system. In turn, the determination of the lake's function in shaping the outflow of the watercourses draining the system is possible by learning the water cycle in the lake, and thus determining the values of the main water exchange flows between the lake and its surroundings (Bajkiewicz-Grabowska 2020b).

In the functioning of each lake, three water exchange fluxes can be determined: the atmospheric ex- 
change flux, the surface exchange flux and the underground exchange flux. Together with the retention difference, they participate in the water balance equation of these reservoirs. Determining all components of the lake's water balance is therefore essential for the functioning of the reservoir itself and has a decisive influence on the determination of the size of the watercourse outflow. While larger lakes often have a permanent runoff, i.e. watercourses flowing out of them constantly drain excess water, smaller reservoirs are often only periodically drained by small watercourses or permanent watercourses with low flow rate (Golus and BajkiewiczGrabowska 2006). Hence, the time and manner of their functioning are strongly related to the amount of water participating in the circulation in a given year.

Small river-lake systems built by small lakes connected by short, often periodic watercourses are common in young glacial areas. As the supply area is small, the outflow from these systems depends on filling the lake basins with water, largely dependent on hydrometeorology. An example of such a small river-lake system is the lobelia lakes systems in the vicinity of the Tri-City in Poland. Lobelia lakes are valuable and rare aquatic geo-ecosystems in which the indicator species are legally protected plants. Despite the increasing number of lobelia lakes undergoing degradation (Kraska 1994a, 1994b; Kraska et al. 2012), few studies focus on the structure of their water balance. Little is known about their influence on the formation of the water network of young glacial areas. The few existing studies assume their water balance is based on the vertical water exchange shaped by precipitation and evaporation (Borowiak et al. 2016).

The purpose of this article is to present the methodology of estimating the components of the lake's atmospheric water exchange flux. In the absence of direct precipitation and evaporation measurements and inadequate selection of the estimation method, this water balance element contributes to the erroneous determination of the lake's hydrological function and the lake's influence on the formation of the river outflow. Consequently, based on insufficiently known specificity of the water cycle, decisions are made that cause changes in the water relations of a given area and increase the risk of lake degradation, including lobelia lakes.

\section{Study area and methods}

A typical small river-lake system in a lake district was chosen to present the methodology for estimating the components of atmospheric water exchange. It is the system of the upper Gościcina River catchment (Fig. 1). The Gościcina, a tributary of the Bolszewka River, is part of the water network of the Reda River drainage basin. In connection with the drainage activities undertaken, the original layout of the river network has recently been transformed, the main engineering work probably carried out at the turn of the twentieth and twenty-first centuries.

An example of the transformation of water conditions in the Gościcina catchment involves Lake Otalżyno and Lake Wysokie, where the change of drainage direction was significant. All available cartographic materials, including the latest hydrographic maps, incorrectly indicate that Lake Otalżyno is a flow-through lake fed mainly from the north by the Struga Otalżyno and drained by a watercourse flowing eastwards to Lake Otalżynko, and then to Lake Wysokie. Even the Map of the Hydrographic Division of Poland (PGW WP 2020) confirms this eastern drainage direction (Fig. 2). Lake Otalżyno and its catchment, according to the situation presented in the Map of the Hydrographic Division of Poland, is the source area of the Gościcina River, the central element in the river-lake system of the lakes Otalżyno, Otalżynko and Wysokie. However, the hydrological measurements carried out in 2008-2010 and the hydrographic mapping of the upper Gościcina River catchment showed that the drainage direction of Lake Otalżyno was different. First, the flow between the lakes Otalżyno and Otalżynko is currently blocked, and there is no connection between these lakes. The flow direction of the Struga Otalżyno has also changed. This watercourse does not supply Lake Otalżyno but drains it throughout the year. As a result, Lake Otalżyno has become a separate geoecosystem with several smaller tributaries, and the watercourse flowing from it - the Struga Otalżyno, directly supplies the Gościcina, which also drains Lake Wysokie. On the west side, Lake Wysokie is supplied by the spring section of the Gościcina, running from Lake Otalżynko. In this section, due to meliorations, the Gościcina has become a periodic watercourse.

Taking into account the changes in the original river-lake system of the upper Gościcina, it was decided to estimate the components of the atmospheric water exchange of the lobelia lakes, which initially formed one river-lake system - Lake Otalżyno (maximum depth 5.9 $\mathrm{m}$, area $80.73 \mathrm{ha}$ ) and Lake Wysokie (maximum depth $7.1 \mathrm{~m}$, area $50.63 \mathrm{ha}$ ).

The flux of atmospheric water exchange, the surface (horizontal) exchange flux, the underground ex- 


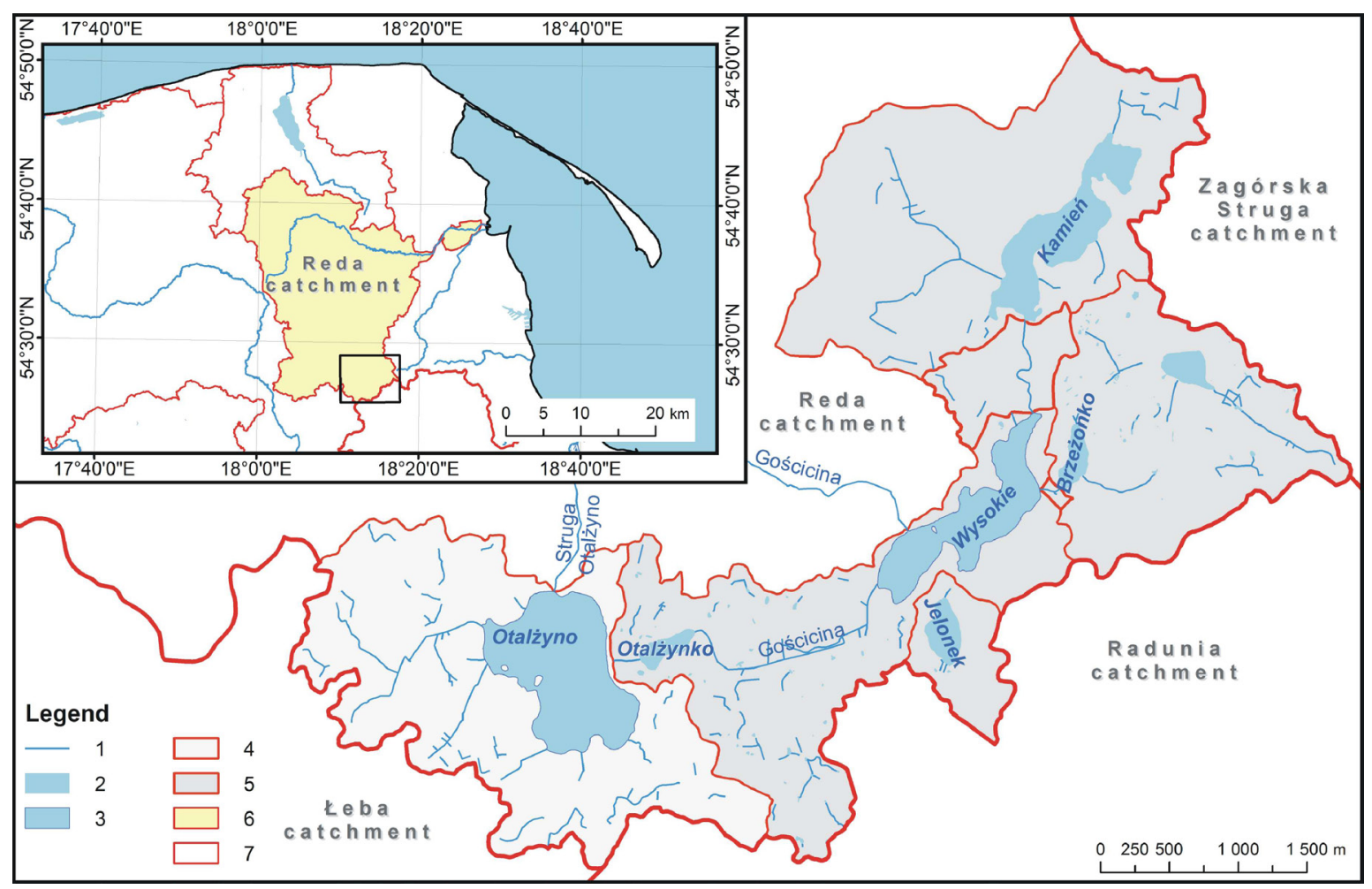

Fig. 1. Simplified hydrography of the river-lake system of the upper Gościcina River. Key: 1 - watercourses, 2 - lakes, 3 - analyzed lobelia lakes, 4 - Lake Otalżyno catchment, 5 - Lake Wysokie river-lake catchment, 6 - Reda River catchment, 7 - other catchments

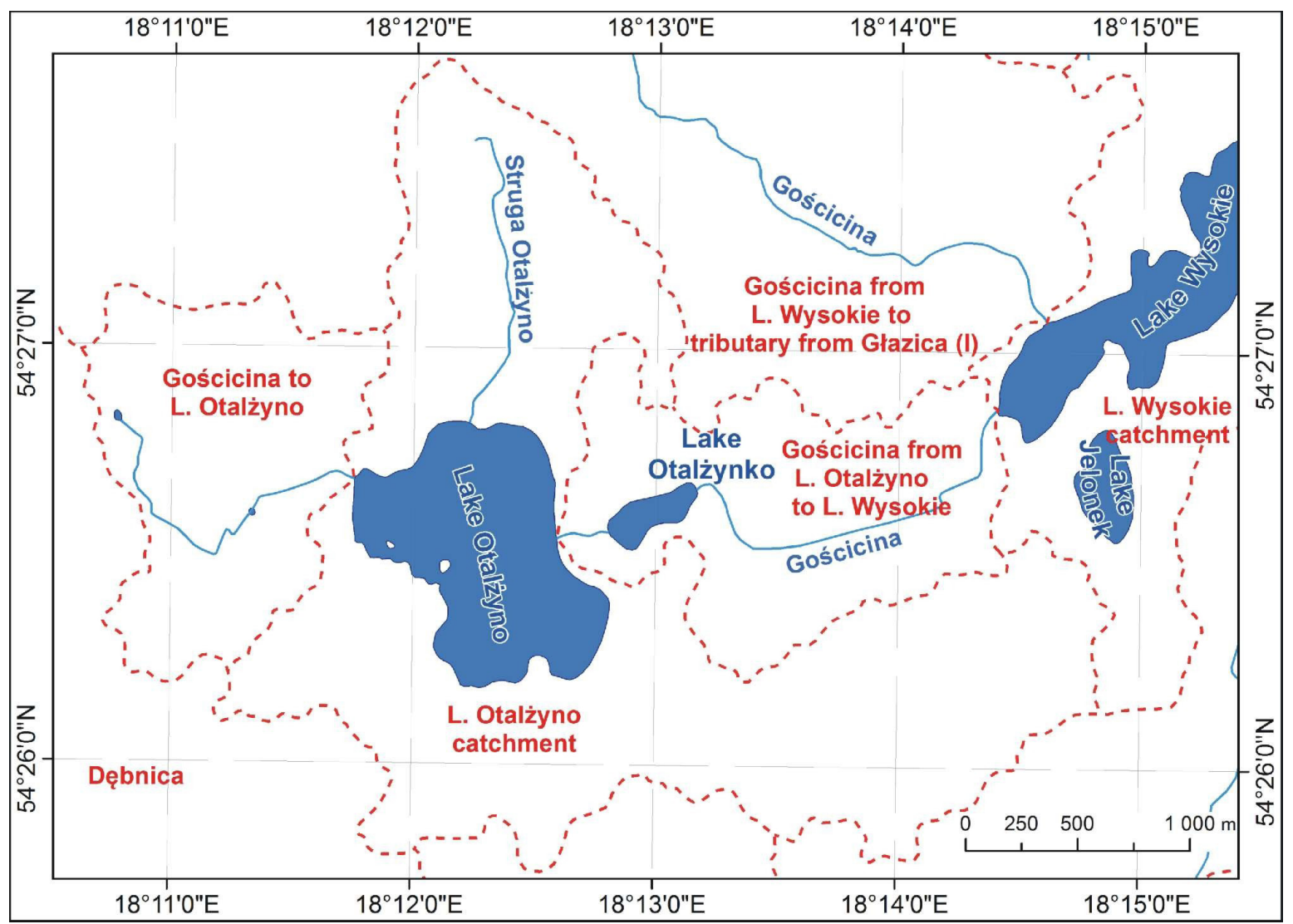

Fig. 2. Hydrographic units of the upper Gościcina River catchment according to Map of the Hydrographic Division of Poland at a scale of 1:10 000 (PGW WP 2020) (Struga Otalżyno according to own materials) 
change flux and the retention difference shape the water exchange in a lake. It can be expressed as the balance equation proposed by Bajkiewicz-Grabowska (1982) (Eq.1) in the following form:

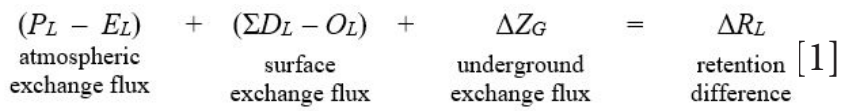

where: $\mathrm{P}_{\mathrm{L}}$ - precipitation on the lake, $\mathrm{E}_{\mathrm{L}}$ - evaporation from the lake, $\Sigma D_{L}$ - the sum of the river and surface inflow from the direct lake catchment, $\mathrm{O}_{\mathrm{L}}-$ river outflow from the lake, $\Delta \mathrm{Z}_{\mathrm{G}}$ - the resultant of the underground supply, i.e. the difference between the underground inflow and outflow, $\Delta \mathrm{R}_{\mathrm{L}}$ - lake retention difference at the beginning and the end of the balanced period; it means the change in the water level in the lake (in $\mathrm{mm}$ ) corresponds to the changes in its capacity $\left[\mathrm{m}^{3}\right]$.

In hydrological studies of river-lake systems, the water balance components are based on direct or indirect hydrological measurements. The ones obtained directly are the values of the surface exchange flux (flows of watercourses, surface runoff) and the retention difference. The atmospheric exchange flux, the difference between the precipitation falling onto the lake and the evaporation from it, is most often based only on the amount of precipitation in the nearest rainfall stations of the IMGW-PIB (Institute of Meteorology and Water Management National Research Institute) measurement network. Only with the values of these water balance elements can we calculate the underground water exchange flux based on the balance difference. Therefore, it is essential to estimate the precipitation falling on the lake and the evaporation volume from the lake, i.e. the vertical (atmospheric) water exchange flux.

While the issue of choosing an appropriate method of estimating the precipitation value falling on a lake in Poland is quite well discussed in the literature (Łupikasza 2007; Bajkiewicz-Grabowska et al. 2012; Szcześniak 2013; Markowski et al. 2015), due to the complexity of the processes of moisture and heat exchange at the interface between water and air (Jaworski and Radecka 1975), it is still challenging.

In this article, to determine the precipitation falling into the lake, it was decided to choose the inverse distance deterministic method (IDW), one of the basic interpolation methods, which gives the results most similar to the real ones (e.g. Keblouti et al. 2012; Noori et al. 2014; Markowski et al. 2015).

The second component of the lake's atmospheric water exchange - evaporation from the lake's surface, is still challenging to measure. A rare network of weather stations measuring actual evaporation from the water surface and the inability to use data from these stations to estimate evaporation from distant objects prompts researchers to use empirical formulas (Kossowska-Cezak and Bajkiewicz-Grabowska 2008). According to Jaworski (1997), "in principle, any known physically justified methods can be used to determine the evaporation". Most often, however, to estimate the evaporation from the surface of lakes, Penman's shortened formula (Eq. 2) is used (Bac 1989; Prządka 2009; Dąbrowski 2011):

$$
E_{w}=0.36 n \cdot d \cdot(1+0.5 v),
$$

where: $\mathrm{E}_{\mathrm{w}}$ - total monthly evaporation from the water surface $[\mathrm{mm}], \mathrm{n}$ - number of days in a month, $\mathrm{d}$ - mean monthly water saturation deficit [mmHg], $\mathrm{v}$ - mean monthly wind velocity $2 \mathrm{~m}$ above the ground in $\mathrm{m} \mathrm{s}^{-1}$.

Nevertheless, studies on evaporation from lakes located in the Kashubian Lake District show that its monthly totals obtained from the shortened Penman formula at the Borucino weather station overstate these values by 20 to $64 \%$ (Konkel 2014). Konkel (2014) indicates that the monthly evaporation totals obtained with the GGI-3000 evaporimeter placed on a raft on Lake Raduńskie Górne are the closest to those obtained with the Davidov formula (Eq. 3). This formula takes the following form (Kossowska-Cezak and BajkiewiczGrabowska 2008):

$$
E_{w}=15 d^{0.8} \cdot(1+0.125 v) .
$$

Symbol designations the same as in Equation 2.

Therefore, the Davidov formula was used to calculate evaporation from the surface of the selected lobelia lakes (Lake Otalżyno and Lake Wysokie). This formula, like Penman's formula, uses the water saturation deficit $\mathrm{d}$ [mm] [Eqs 4-5], which the following formula can represent:

$$
\begin{gathered}
d[\mathrm{hPa}]=E[\mathrm{hPa}]-e[\mathrm{hPa}], \\
d[\mathrm{mg} \mathrm{Hg}]=d[\mathrm{hPa}] \cdot 0.750 .
\end{gathered}
$$

The mean monthly water saturation deficit $d$ $[\mathrm{hPa}]$ was calculated as the difference in saturated water vapour pressure under the conditions of the mean monthly surface water temperature of the lake $\mathrm{E}$ [hPa] and the mean monthly water vapour pressure in the air 
e $[\mathrm{hPa}$. The saturated water vapour pressure E (Eq. 6) under the conditions of the monthly mean lake surface water temperature (TWP) was calculated according to ISO 13788 standard (PN-EN ISO 13788:2013) from the following correlation:

$$
E=610.5 \cdot \exp \left(\frac{17.269 \cdot T W P}{237.3+T W P}\right)
$$

where: $\mathrm{E}$ - water vapour pressure in the conditions of the monthly mean water temperature of a given lake $[\mathrm{Pa}]$; TWP - monthly mean surface water temperature $\left[{ }^{\circ} \mathrm{C}\right]$ of a given lake (assumed to be equal to the surface water temperature of the lake on the measurement day).

The monthly mean water vapour pressure in the air at the lake e $[\mathrm{hPa}]$ was calculated from the following equation:

$$
e=\frac{E \cdot f}{100},
$$

where: E - monthly water vapour pressure in the conditions of the monthly mean water temperature of a given lake $[\mathrm{hPa}], \mathrm{f}$ - monthly mean relative air humidity [\%]

Data on the mean monthly wind velocity and the mean monthly relative air humidity were obtained from the ARMAAG (Regional Atmosphere Monitoring Agency in the Gdańsk Agglomeration) weather station in Szadółki. In turn, the mean monthly surface water temperature of individual lakes was obtained from field measurements taken in the three hydrological years 2008-2010. Hence, the component of atmospheric water exchange in the lakes Otalżyno and Wysokie was estimated for years 2008-2010, diverse in terms of humidity (regular, humid and extremely humid year) and thermal conditions (slightly cool, slightly warm and very warm year) (Markowski 2018).

\section{Results}

Annual sums of atmospheric precipitation hitting the surface of the studied lobelia lakes in the humid and very warm year 2008 and the regular and slightly warm year 2009 are similar and amount to about $740 \mathrm{~mm}$ (Fig. $3 \mathrm{~A})$. Much higher precipitation totals were recorded in 2010, which was a very humid and slightly warm year. Annual precipitation totals at Lake Otalżyno were then almost $30 \mathrm{~mm}(813 \mathrm{~mm})$ lower than at Lake Wysokie $(839 \mathrm{~mm})$. These values indicate the importance of selecting a methodology for estimating precipitation that considers the influence of local conditions of reservoirs located at a distance of only slightly more than $2 \mathrm{~km}$.

In the wet winter half-year of 2008, the highest monthly precipitation was recorded in November (nearly $90 \mathrm{~mm}$ ) and March (96-98 $\mathrm{mm}$ ), and the lowest in December (up to $30 \mathrm{~mm}$ ) and February (up to 35 $\mathrm{mm}$ ), while in the summer half-year this year, regular in terms of precipitation, the highest monthly totals were recorded in August (over $110 \mathrm{~mm}$ ), and the lowest in October (about $54 \mathrm{~mm}$ ) (Fig. 3B).

The winter half of 2009 was dry. As in 2008, the highest precipitation was recorded in November and March (64-67 mm), the lowest in January (up to $30 \mathrm{~mm}$ ) and April (only $0.8 \mathrm{~mm}$ ) (Fig. 3C). The summer half-year of 2009 was humid. The highest monthly precipitation totals occurred in July (approximately 144 $\mathrm{mm}$ ) and October (113-114 mm), and the lowest in August (35-37 mm).

In 2010, the winter half-year precipitation did not differ from the norm. The lakes received the most precipitation in December (57-60 mm) (Fig. 3D). The summer half-year was extremely humid. In May, over $104 \mathrm{~mm}$ of precipitation fell on the examined lobelia lakes, while in July and August from $139 \mathrm{~mm}$ (Lake Otalżyno) to $146 \mathrm{~mm}$ (Lake Wysokie). The lowest values of atmospheric water supply were recorded in June (slightly over $18 \mathrm{~mm}$ ) and October (approximately 29 $\mathrm{mm})$.

The adopted methodology for estimating the amount of evaporation from the studied lakes assumes it depends on the temperature of their surface water, shaped by the air temperature.

The highest annual evaporation totals from the surface of the examined lakes were recorded in 2008, very warm in thermal terms (Fig. 4A). That year, nearly $627 \mathrm{~mm}$ of water evaporated from Lake Otalżyno and about $10 \mathrm{~mm}$ less from Lake Wysokie. In 2009, slightly warm, the difference in the evaporated water was by far the largest and amounted to almost $19 \mathrm{~mm}$ (Lake Otalżyno: $587.2 \mathrm{~mm}$, Lake Wysokie: $568.5 \mathrm{~mm}$ ). On the other hand, in 2010, slightly cool, the lowest evaporation values were recorded (Lake Otalżyno: $563.1 \mathrm{~mm}$, Lake Wysokie: $556.3 \mathrm{~mm}$ ). That year, the difference in the amount of evaporation between the lakes was less than $7 \mathrm{~mm}$.

The course of monthly evaporation totals from the studied lobelia lakes in all analysed hydrological years is similar. The amount of water evaporated from the lakes in the summer half-year was generally $69-71 \%$ of the annual total. 


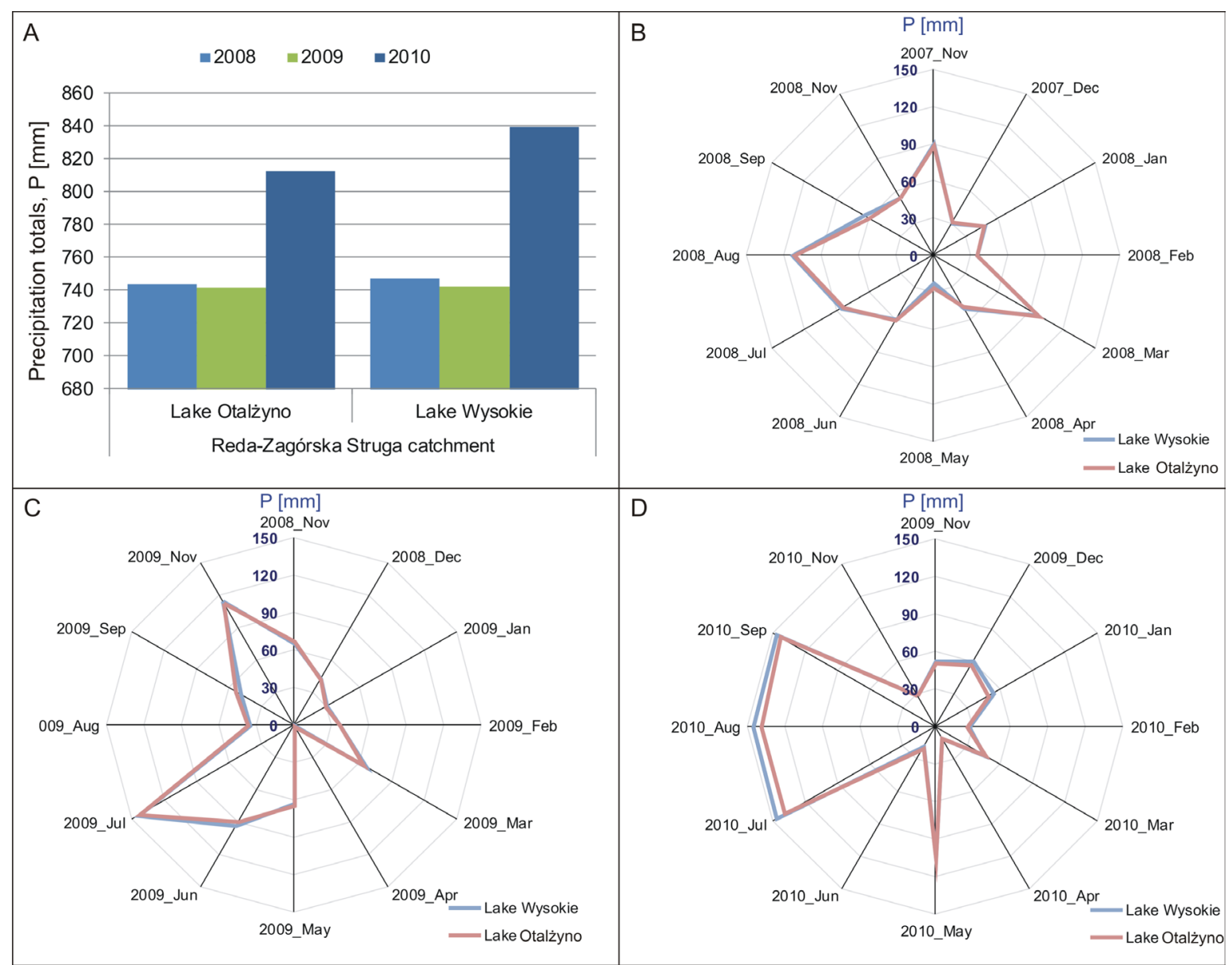

Fig. 3. Annual (A) and monthly (B, C, D) atmospheric precipitation totals, P, supplying the studied lobelia lakes in the hydrological years 2008-2010

In 2008 the winter half-year was very warm, which influenced the total amount of evaporated water from the lakes. In those six months, the most water evaporated in April (Lake Otalżyno: $53.5 \mathrm{~mm}$, Lake Wysokie: $58.8 \mathrm{~mm}$ ), and the least in December (Lake Otalżyno: $18.0 \mathrm{~mm}$, Lake Wysokie: $18.3 \mathrm{~mm}$ ) (Fig. 4B). The warm summer half-year of the hydrological year 2008 showed the highest evaporation from both lakes. It was $436.5 \mathrm{~mm}$ for Lake Otalżyno, and $421.3 \mathrm{~mm}$ for Lake Wysokie. June that year turned out to be recordbreaking, with evaporation over $109 \mathrm{~mm}$.

In terms of thermal conditions, the winter half of 2009 was slightly warm. The largest amount of water evaporated in April (Lake Otalżyno: $79 \mathrm{~mm}$, Lake Wysokie: $76.6 \mathrm{~mm}$ ), and the least in December - about $12.7 \mathrm{~mm}$ from both lakes (Fig. 4C). The humid summer half of 2009 did not differ from the norm in terms of temperature. The greatest amount of water evaporated in August (Lake Otalżyno: $105.4 \mathrm{~mm}$, Lake Wysokie: $99.9 \mathrm{~mm}$ ), and the least in October - $32.3 \mathrm{~mm}$ on aver- age.

The winter half of 2010 was thermally cool. The lowest evaporation in that half-year $(14.8-15.0 \mathrm{~mm})$ was recorded in December, while the highest in April (Lake Otalżyno: $54.9 \mathrm{~mm}$, Lake Wysokie: $52.6 \mathrm{~mm}$ ) (Fig. 4D). In the summer half-year of 2010, extremely humid but regular in terms of thermal conditions, the most water evaporated from the lakes in July - over $98 \mathrm{~mm}$, while the least in October - slightly over $35 \mathrm{~mm}$ (Fig. 4D).

Once the value of the atmospheric water supply to the lake (precipitation) and the evaporation of water from its surface are known, it is possible to determine the water exchange flux between the lake and the atmosphere. When the difference between the amount of water falling onto the lake and evaporating from it is positive, there is a surplus of water in the vertical exchange. A negative sign of this difference indicates a water deficit.

The atmospheric water exchange flux size in individual years of 2008-2010 depended on the meteo- 


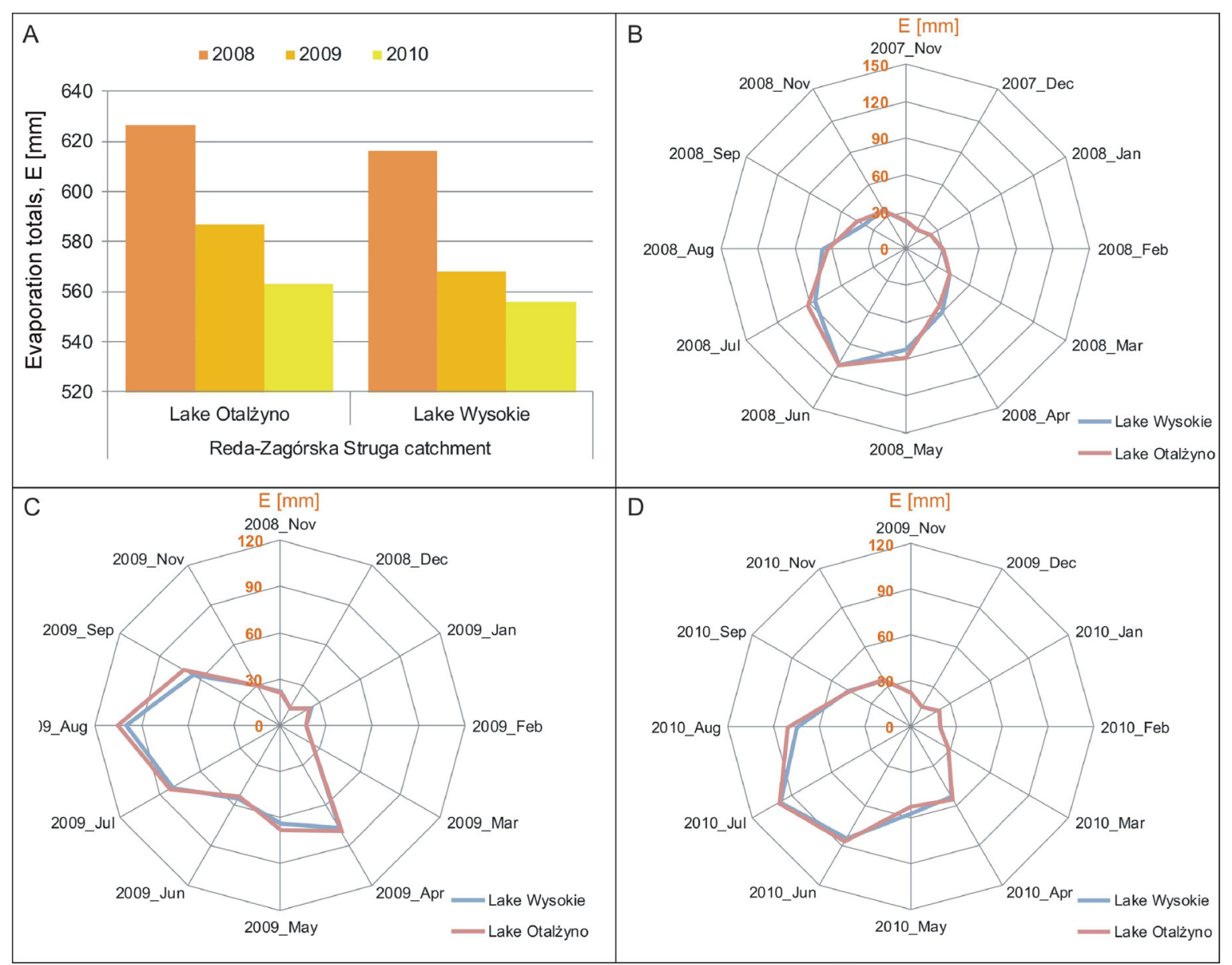

Fig. 4. Annual (A) and monthly (B, C, D) evaporation totals, E, from the studied lobelia lakes in the hydrological years 2008-2010

rological conditions, i.e. precipitation, air temperature and wind velocity. Despite good humidity conditions (wet year), the lowest water surplus in the studied lobelia lakes was in 2008. The high mean monthly air temperatures resulted in relatively high values of evaporation from the water surface, which resulted in relatively low values of the vertical water exchange flux, amounting to $131.4 \mathrm{~mm}$ for Lake Otalżyno and $117.2 \mathrm{~mm}$ for Lake Wysokie (Fig. 5). In 2009, with regular precipitation and slightly warm, the annual water surplus resulting from the exchange between the atmosphere and the lakes ranged from $155.2 \mathrm{~mm}$ (Lake Otalżyno) to 174.0 $\mathrm{mm}$ (Lake Wysokie). Slightly higher values of the vertical exchange flux than 2008, with similar annual precipitation totals, resulted from the lower amount of water evaporated from the lakes (Fig. 5). The highest water surpluses were recorded in the humid but slightly cool hydrological year 2010. Very good humidity conditions, combined with evaporation reaching 556-563 $\mathrm{mm}$, caused the water surplus to be almost twice as high as in 2008 (Lake Otalżyno: $250.2 \mathrm{~mm}$, Lake Wysokie: $283.5 \mathrm{~mm}$ ) (Fig. 5).

The year 2008 turned out to be particularly dynamic in terms of the distribution of monthly water exchange flux between the atmosphere and the studied lakes. The water surplus in the winter half-year was $152.9 \mathrm{~mm}$ (Lake Wysokie) and $155.9 \mathrm{~mm}$ (Lake Otalżyno). On the other hand, in the summer half-year, water deficits were recorded for both Lake Otalżyno $(-38.9 \mathrm{~mm})$ and Lake Wysokie $(-21.5 \mathrm{~mm})$. Monthly atmospheric water exchange fluxes were positive from November to March. In March, the amount of water from the atmospheric exchange accumulated in the lakes was $161.7 \mathrm{~mm}$ for Lake Otalżyno and $162.4 \mathrm{~mm}$ for Lake Wysokie. In the summer half-year, the surplus of water from the atmospheric supply stored in the lakes decreased, reaching the lowest level in May $(-62.2 \mathrm{~mm}$ for Lake Otalżyno, $-59.6 \mathrm{~mm}$ for Lake Wysokie) (Fig. $6 \mathrm{~A})$. These resources were replenished in the coming months. 


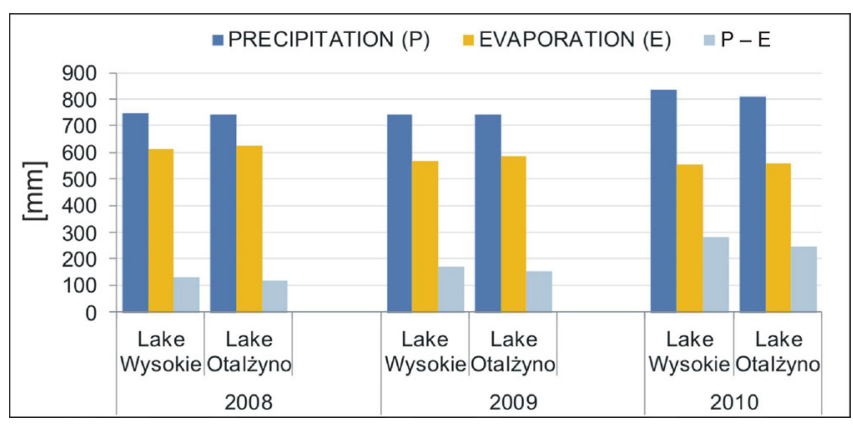

Fig. 5. The components of the atmospheric water exchange in the studied lobelia lakes in 2008-2010

In 2009 and 2010, the vertical water exchange fluxes in the winter and summer half-years generated a water surplus. In 2009, for Lake Otalżyno, these surpluses were $64.8 \mathrm{~mm}$ in the winter half-year, $90.4 \mathrm{~mm}$ in the summer half-year. In 2010 they were $77.3 \mathrm{~mm}$ in the winter half-year and $172.9 \mathrm{~mm}$ in the summer half-year. In the winter half-year of 2009, Lake Wysokie showed a water surplus of $67.8 \mathrm{~mm}$, and in the summer half-year, $106.2 \mathrm{~mm}$. Significantly higher values of the atmospheric water exchange flux in this lake were recorded for 2010 (winter half-year: $90.5 \mathrm{~mm}$, summer half-year: $193.0 \mathrm{~mm})$.

The hydrological year 2009, with a dry winter half-year and a humid summer half-year, began with a surplus of the vertical water exchange flux of 45.8 $\mathrm{mm}$ for Lake Otalżyno and $43.4 \mathrm{~mm}$ for Lake Wysokie. These surpluses grew until March when their mean state in the lakes was approximately $143.5 \mathrm{~mm}$ (Fig. 6B). In April and May, they started to decrease, and from June onwards, they started a rise again, reaching in July a higher level than in March - a mean of $164.1 \mathrm{~mm}$. The following two months showed a water deficit, which meant the water surplus stored in the lakes decreased. They were supplemented with a positive flux of atmospheric exchange in October, reaching $155.1 \mathrm{~mm}$ for Lake Otalżyno and $174.1 \mathrm{~mm}$ for Lake Wysokie at the end of the hydrological year (Fig. 6B).

The hydrological year 2010, with the winter halfyear with average precipitation and the extremely humid summer half-year, both lakes started with a water reserve: $28.8 \mathrm{~mm}$ in Lake Otalżyno, and $30.0 \mathrm{~mm}$ in Lake Wysokie. Water surpluses in the following months were gradually increasing until March. A higher growth dynamic was recorded for Lake Wysokie - an increase of $102.6 \mathrm{~mm}$, while an increase in Lake Otalżyno was by $93.2 \mathrm{~mm}$ (Fig. 6C). The following months (April, May and June) brought a fluctuation (decrease - increase decrease) in stored water. The April and June water deficits were filled in May and the following months from July to October. At that time, a very dynamic increase in water resources was recorded in both lakes. Consequently, at the end of the hydrological year 2010, water surpluses were recorded, reaching $250 \mathrm{~mm}$ in Lake Otalżyno and $283 \mathrm{~mm}$ in Lake Wysokie (Fig. 6C).

The presented analysis of the evaporation estimated with the Davidov formula and the precipitation values determined by the IDW interpolation method indicates a systematic supply of water to the studied lakes resulting from the excess precipitation over evaporation. Therefore, the direction of the atmospheric water exchange flux concerning annual totals, regard-
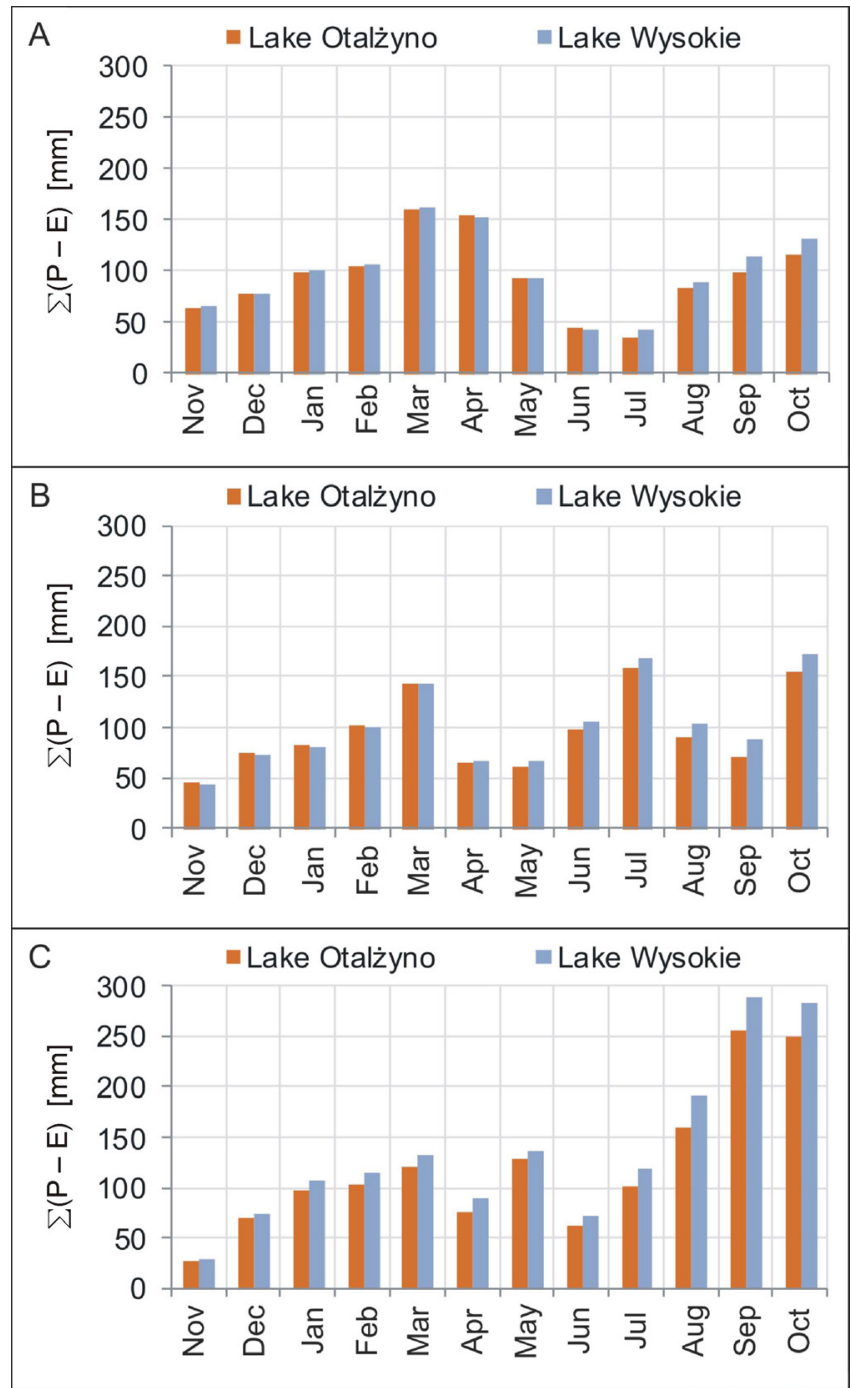

Fig. 6. The sum of monthly surpluses and deficits of atmospheric water exchange in the studied lobelia lakes in the hydrological years 2008 (A), 2009 (B), and 2010 (C) 
less of the water content of a given year, was stable and assumed positive values, but its values were different every year.

\section{Discussion and conclusion}

The presented methodology for estimating atmospheric water exchange on the example of a river-lake system of lobelia lakes in the vicinity of the Tri-City uses the Davidov formula to calculate evaporation from the lakes. However, it should be emphasised that the humidity conditions, which determine evaporation from the lakes, are significantly more strongly influenced by the lake water temperature and not the air temperature, very often recorded at distant weather stations. Therefore, the monthly evaporation totals from the analysed lakes were calculated using the saturated water vapour pressure E considering the monthly mean lake surface water temperature (TWP) and not the monthly mean air temperature at the weather station. For this purpose, the formula recognised in the current ISO 13788 standard (PN-EN ISO 13788:2013) concerning the hygrothermal properties of components and buildings' elements was used. The proposed approach considers the lake's local conditions, which means that the evaporation from the surface of the lakes located in the same region with the same or very similar climatic conditions may be quite different (Bac and Rojek 1999).

The flux of atmospheric water exchange between the lake and the atmosphere, being the difference between the atmospheric water supply to the lake (atmospheric precipitation) and water evaporation from its surface in particular years of the research period, was dependent on the meteorological conditions of a given year. In the entire research period (2008-2010), the annual atmospheric water exchange flux was positive. While the annual fluxes of atmospheric water exchange supplying lakes for the period 2008-2009 were not very diverse, its values for 2010 indicate that it may play a decisive role in the water cycle in the lake, especially in extreme years in terms of total annual precipitation. Much greater differentiation in the size of the atmospheric water exchange flux was visible in monthly intervals. In the months with the water deficits from vertical water exchange with a simultaneous unfavourable underground and surface supply system, no runoff was recorded in the drainage watercourse of Lake Wysokie (Fig. 7A). It is evident from May to October 2008, preceded by three months (from April to June) of water deficit resulting from the atmospheric water exchange (Fig. 6A).
In 2009-2010, the lack of runoff from Lake Wysokie was recorded three times: in June and September 2009 and in July 2010. Also, in these cases, they were preceded by short-term (monthly) water deficits resulting from vertical water exchange. It is worth noting that Lake Wysokie closes a typical small river-lake system. Hence its reaction to water losses related to the atmospheric exchange flux is visible in the characteristics of the watercourse flowing out of it with an inevitable delay of one or two months.

Lake Otalżyno, which used to be the first link in the river-lake system, is fed by three periodical watercourses and drained by the permanent Struga Otalżyno. One might suppose that the change of water relations here should result in greater sensitivity of the watercourse to water shortages resulting from the negative flux of atmospheric water exchange. Even during water shortages (April-May-June 2008, April and August 2009, April 2010), only a decrease in the watercourse flow was observed (Fig. 7B). In the hydrological years 2008-2010, no periods were recorded in which the Struga Otalżyno had zero water flows. It proves the critical role of the underground water exchange flux and active retention of the lake catchment in the water cycle in this lake and the outflow from it (Markowski 2018).

A complete and correct understanding of the functioning of lakes and their impact on the outflow is possible only if all components of the water cycle balance in the lake are known. The detailed studies of the water balance structure of lobelia lakes to date (Markowski 2018) indicate that the balance equilibrium (determining the relative durability of the lake's geoecosystem (Bajkiewicz-Grabowska 2008) is achieved thanks to active retention (the amount of water participating in the water cycle). As evidenced by numerous studies of lakes in the lake district landscape (e.g. Okulanis 1985; Borowiak 2000; Bajkiewicz-Grabowska 2008; Dąbrowski 2011), the element which disturbs the balance is very often the atmospheric water exchange flux. It is responsible for generating water surpluses, which form surface runoff, supply groundwater, and increase surface retention (including lake retention) and underground retention. Hence, in river-lake systems, water circulation in the lakes determines the constancy and size of the outflow via draining watercourses. With a high level of lake retention, when the lake basins are full, the flow of the watercourse increases, while at a low level, the flow decreases or completely disappears (Bajkiewicz-Grabowska 2008; Bajkiewicz-Grabowska and Golus 2009). 


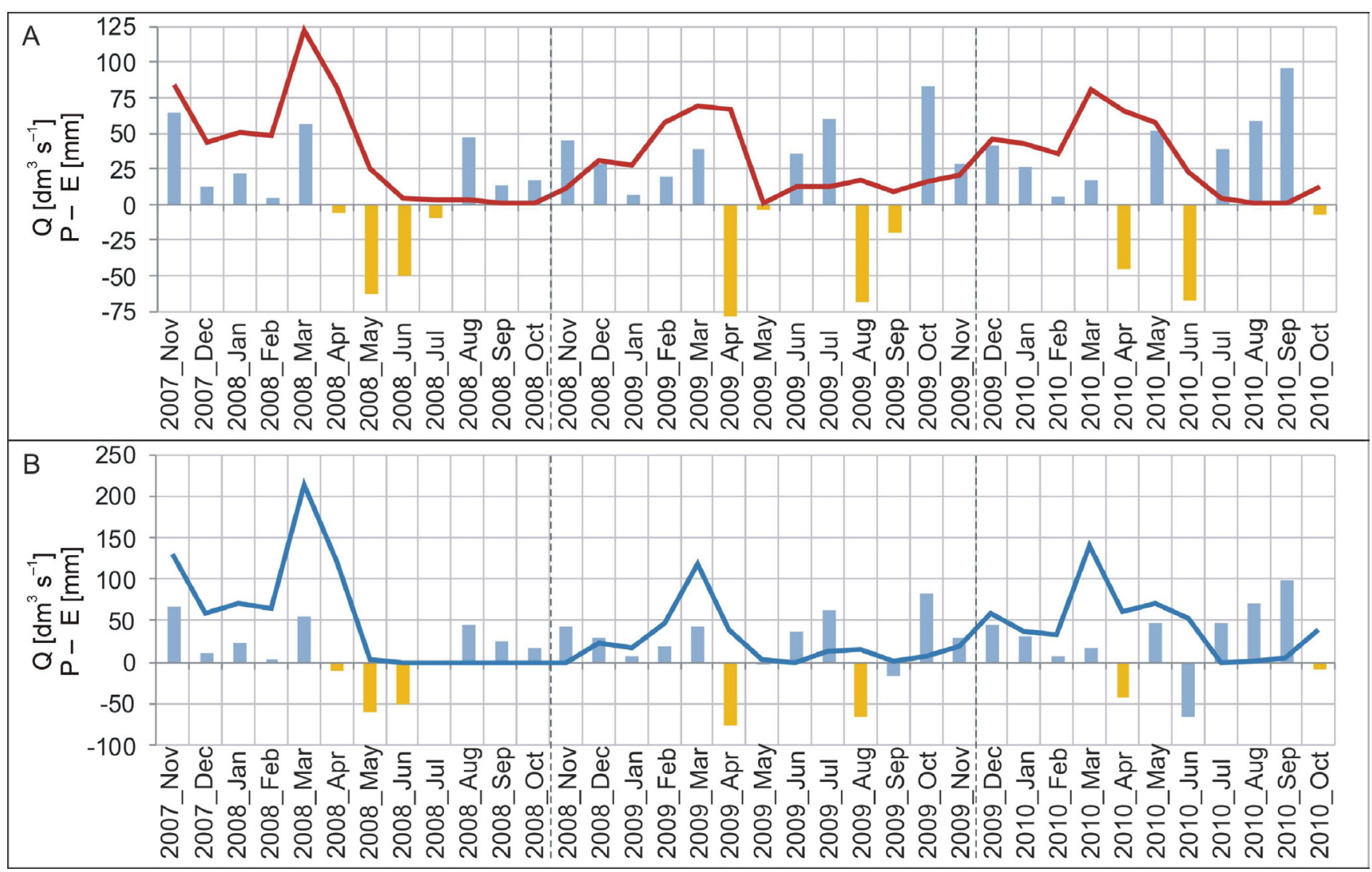

Fig. 7. Monthly river runoff, $Q$ (line graph), against monthly water exchange fluxes $P$ - E (bar graph) for the examined lakes: Wysokie (A), and Otalżyno (B)

The conditions of water circulation in the lake and the processes shaping them are crucial for the functioning of the surface runoff from a given lake. In the context of transformations of water conditions within the catchment of the upper Gościcina river-lake system, the lack of access to previous monitoring studies on the water circulation and resources makes it impossible to unequivocally assess whether the measures taken harmed the outflow from this system. Based on the calculations carried out, it can be assumed that the original system in which the water from Lake Otalżyno reached Lake Wysokie through Lake Otalżynko guaranteed a stable and constant outflow from the entire system of the upper Gościcina River. In the current hydrographic system, there are regular periods when the Gościcina does not drain Lake Wysokie. The periodicity of the Gościcina caused problems in the functioning of the sewage treatment plant constructed in 2008 in Szemud (below Lake Wysokie). Therefore, to save the investment, the Otalżyno and Wysokie lakes were dammed to ensure constant and appropriate flow in the watercourses draining the lakes and increase lake retention. When making the decision, the fact that these lakes are home to legally protected plant communities was not considered. Knowing the specificity of the depth range tolerated by these plants, one can risk a statement (no current research in this regard) that the consequence of the construction of locks on both lakes in 2012 is a partial degradation of their population.

Questionable decisions have led to unjustified water management activities. The environmental, financial and social losses suffered indicate the need to apply an appropriate methodology for assessing water circulation conditions in river-lake systems.

\section{References}

Bac S., 1989, Współzależność miesięcznych i dekadowych wielkości ewapotranspiracji według Penmana $\mathrm{z}$ parowaniem $\mathrm{z}$ wolnej powierzchni wodnej w świetle dwudziestoletnich badań (Monthly and decadal evapotranspiration after Penman on interrelation between evaporation from free water surface in the light of twenty-years investigation), Zesz. Nauk. AR Wrock. 181: 99-109 (in Polish, English summary).

Bac S., Rojek M., 1999, Meteorologia i klimatologia w inżynierii środowiska (Meteorology and climatology 
in environmental engeeniring), Wydaw. AR Wrocł., Wrocław, 314 pp (in Polish).

Bajkiewicz-Grabowska E., 1982, Określenie elementów bilansu wodnego oraz ocena użytkowania ziemi i antropopresja w zlewni jeziora Wigry (Determination of the water balance elements, land use assessment, and anthropopressure in the Lake Wigry catchment) [Manuscript], Inst. Ekol. PAN (in Polish).

Bajkiewicz-Grabowska E., 2002, Obieg materii w systemach rzeczno-jeziornych (Circulation of matter in the river-lake systems), Wydaw. UW, Wydział Geografii i Studiów Regionalnych, Warszawa, 274 pp (in Polish, English summary).

Bajkiewicz-Grabowska E., 2007, Jeziorne ogniwa w sieci hydrograficznej obszarów młodoglacjalnych i ich rola w kształtowaniu odpływu rzeki pojeziernej (Lakes as elements of hydrographic network of the late glacial landscape and their role in the runoff generation of the lake-river system), [in:] Michalczyk Z. (ed.), Obieg wody $\mathrm{w}$ środowisku naturalnym i przekształconym (Water circulation in natural and transformed environment), Badania hydrograficzne w poznawaniu środowiska 8, Wydaw. UMCS, Lublin: 39-46 (in Polish).

Bajkiewicz-Grabowska E., Borowiak D., Tórz A., Nędzarek A., Markowski M., Grabowska B., Trusewicz Z., Fabich A., 2012, Weryfikacja wyznaczenia silnie zmiennych części wód jeziornych wraz ze szczególowym uzasadnieniem (Verification of the determination of highly variable lake water bodies with detailed justification) [Typescript], RZGW Szczec., Szczecin, 230 pp (in Polish).

Bajkiewicz-Grabowska E., Golus W., 2009, Organizacja sieci hydrograficznej w zlewni pojeziernej przy różnym stanie jej retencji (Hydrographic network layout in lake catchment areas at various retention levels), [in:] Bogdanowicz R., Fac-Beneda J. (eds), Zasoby i ochrona wód. Obieg wody i materii w zlewniach rzecznych (Water resources and water protection. Water and matter cycling in river basins), Wydaw. FRUG, Gdańsk: 159-166 (in Polish, English summary).

Bajkiewicz-Grabowska E., Golus W., Markowski M., Kwidzińska M., 2020a, Characteristics of the water network in postglacial areas of northern Poland, [in:] Korzeniewska E., Harnisz M. (eds), Polish river basins and lakes - Part I. Hydrology and hydrochemistry, The Handbook of Environmental Chemistry 86, Springer, Cham:159-174.

Bajkiewicz-Grabowska E., Golus W., Markowski M., Kwidzińska M., 2020b, The role of lakes in shaping the runoff of lakeland rivers, [in:] Korzeniewska E., Harnisz M. (eds), Polish river basins and lakes - Part I. Hydrology and hydrochemistry, The Handbook of Environmental Chemistry 86, Springer, Cham:175-187.

Borowiak D., 2000, Reżimy wodne i funkcje hydrologiczne jezior Niżu Polskiego (Water regimes and hydrological functions of Polish Lowland lakes), Bad. Limnol. 2, Wydaw. KLUG, Gdańsk, 164 pp (in Polish,
English summary).

Borowiak D., Nowiński K., Borowiak M., Grabowska K., 2016, Środowisko abiotyczne ekosystemów jezior lobeliowych (The abiotic environment of lobelia lakes ekosystems), [in:] Bociąg K., Borowiak D. (eds), Jeziora lobeliowe w drugiej dekadzie XXI wieku. Program kompleksowej ochrony jezior lobeliowych w Polsce. Etap I. Podstawy, modelowe rozwiązania (Lobelia lakes in the second decade of $21^{\text {th }}$ century. The programme of comprehensive conservation lobelia lakes in Poland. Step 1 . The grounds and showcase solutions), Wydaw. FRUG, Gdańsk: 20-51 (in Polish, English summary).

Dąbrowski M., 2011, Uwarunkowania naturalne i antropogeniczne obiegu wody w Systemie Wielkich Jezior Mazurskich (Natural and anthropogenic conditions of the water cycle in the Great Masurian Lakes System) [Dissertation], Wydaw. IMGW-PIB, Warszawa, 426 pp (in Polish).

Drwal J., 1982, Wykształcenie i organizacja sieci hydrograficznej jako podstawa oceny struktury odpływu na terenach młodoglacjalnych (Form and organization of the hydrographic network as an indicator for the assessment of the outflow-structure in young-glacial areas), Zesz. Nauk. Wydz. BiNoZ UG, Rozpr. Monogr. 33, Gdańsk, 130 pp (in Polish, English summary).

Golus W., Bajkiewicz-Grabowska E., 2016, Water circulation in the moraine ponds of northern Poland, Hydrobiologia 793(1): 55-65.

Jaworski J., 1997, Parowanie terenowe (Evaporation), [in:] Soczyńska U. (ed.), Hydrologia dynamiczna (Dynamic Hydrology), Wydaw. Nauk. PWN, Warszawa: 139-184 (in Polish).

Jaworski J., Radecka E., 1975, Podstawy teoretyczne wyznaczania procesów parowania i ewapotranspiracji (Theoretical basis for determination of evaporation and evapotranspiration processes), Prz. Geofiz. 20(2): 79-96 (in Polish, English summary).

Keblouti M., Ouerdachi L., Boutaghane H., 2012, Spatial interpolation of annual precipitation in Annaba-Algeria - Comparison and evaluation of methods, Energy Procedia 18: 468-475.

Konkel Ł., 2014, Sezonowa zmienność klimatycznego bilansu wodnego (Seasonal dynamics of climatic water balance) [Thesis], Uniwersytet Gdański - Katedra Limnologii, Gdańsk, 59 pp (in Polish).

Kossowska-Cezak U., Bajkiewicz-Grabowska E., 2008, Podstawy hydrometeorologii (Principles of hydrometeorolgy), Wydaw. Nauk. PWN, Warszawa, 253 pp (in Polish).

Kraska M. (ed.), 1994a, Jeziora lobeliowe. Charakterystyka, funkcjonowanie i ochrona. Cz. I (Lobelia lakes. Characteristics, functioning and protection. Part I), Idee Ekol. 6, ser. Szkice 4, Poznań, 177 pp (in Polish). Kraska M. (ed.), 1994b, Jeziora lobeliowe. Charakterystyka, funkcjonowanie i ochrona. Cz. II (Lobelia lakes. Characteristics, functioning and protection. Part II), 
Idee Ekol. 6, ser. Szkice 5, Poznań, 105 pp (in Polish).

Kraska M., Klimaszyk P., Piotrowicz R., 2012, Zarybianie jako antropogeniczna przyczyna niestabilności i zmian struktur przestrzennych roślinności lobeliowego Jeziora Modrego (Łupalickiego) na Pojezierzu Bytowskim (Fishstocks as an anthropogenic cause of instability and changes in spatial structures of vegetation in the lobelian Lake Modre (Eupalickie) in Bytów Lake District), Bad. Fizjogr. 3(B61): 123-153 (in Polish, English summary).

Łupikasza E., 2007, Wieloletnia zmienność występowania ekstremów opadowych w Hornsundzie (Spitsbergen) i ich związek z cyrkulacją atmosfery (Long-term variability of extreme precipitation in Hornsund (Spitsbergen) and their relation with atmospheric circulation), Probl. Klim. Polar. 17: 87-103 (in Polish, English summary).

Markowski M., 2018, Hydrologiczne uwarunkowania funkcjonowania jezior lobeliowych okolic Trójmiasta (Hydrological conditions of Lobelia Lakes functioning in the Vicinity of the Tri-City) [Dissertation], Uniwersytet Gdański - Zakład Limnologii, Gdańsk, 447 pp (in Polish).

Markowski M., Golus W., Kwidzińska M., 2015, Aplikacyjność metod oceny wielkości opadów zasilających oczka Pomorza Gdańskiego (The applicability of methods to estimate precipitation that recharges ponds in Gdańsk Pomerania), [in:] AbsaIon D., Matysik M., Ruman M. (eds), Nowoczesne metody i rozwiązania $w$ hydrologii i gospodarce wodnej (Novel methods and solutions in hydrology and water management), Monogr. Kom. Hydrol. PTG 3, Sosnowiec: 287-298 (in Polish, English summary).

Noori J. M., Hussein H. H., Yassen T. M., 2014, Spatial estimation of rainfall distribution and its classification in Duhok Governorate using GIS, J. Water Resour. Prot. 6(2): 75-82.

Okulanis E., 1985, Rola jezior w kształtowaniu stosunków hydrologicznych w wybranych zlewniach rzek Pojezierza Kaszubskiego (The role of lakes in the determination hydrological relations in selected river drainage areas of the Cassubian Lakeland), Zesz. Nauk. Wydz. BGiO UG, Geografia 14: 31-44 (in Polish, English summary).

[PGW WP] Państwowe Gospodarstwo Wodne Wody Polskie (State Water Holding Polish Waters), 2020, Hydroportal. Mapa Podziału Hydrograficznego Polski (MPHP) 1: 10000 (Hydroportal. Map of the Hydrographic Division of Poland 1:10 000) [Electronic resource], PGW WP (Accessed 21 February 2021). Retrieved from https://wody.isok.gov.pl/imap_ $\mathrm{kzgw} /$ ?gpmap=gpPDF

PN-EN ISO 13788:2013 Cieplno-wilgotnościowe właściwości komponentów budowlanych i elementów budynku. Temperatura powierzchni wewnętrznej konieczna do uniknięcia krytycznej wilgotności powierzchni i kondensacji międzywarstwowej. Metody obliczania (Hygrothermal characteristics of building elements. Internal surface temperature necessary to avoid critical surface moisture and interlayer condensation. Calculation methods), PKN, Warszawa (Polish version).

Prządka Z., 2009, Porównanie wyników oceny parowania jeziora Łękuk uzyskanych metodą obliczeniową i pomiarową (Comparision of evaporation estimation results for Łękuk Lake obtained by calculated and measurment methods), Monit. Środ. Przyr. KTN 10: 73-78 (in Polish, English summary).

Szcześniak M., 2013, Wpływ metod opracowania wejściowych danych meteorologicznych na symulacje przepływów w zlewni Pilicy z wykorzystaniem modelu SWAT (Effect of methods for the development of input meteorological data on the simulation of discharge in the Pilica catchment using the SWAT model) [Thesis], SGGW - Katedra Inżynierii Wodnej, Warszawa, 82 pp (in Polish). 